\title{
TÉNYKÉP
}

\author{
Varga Ágnes
}

\section{A vállalkozások térbeli koncentrációjának változása Borsod-Abaúj-Zemplén megye perife- rikus járásaiban}

A kutatás Borsod-Abaúj-Zemplén megye és járásainak a müködö vállalkozások számának és a vállalkozássürüség területi különbségeinek, annak elsősorban a periférikus járásokra fókuszáló értékelésén és a háttérben meghúzódó lehetséges okok feltárásán keresztül arra is felhívja a figyelmet, hogy a nem feltétlenül népességhez kötödö gazdasági jellemzök népességarányos vizsgálata hogyan viheti félre a kutatót az egyes területi egységek növekedésének, fejlödésének megitélésében.

Kulcsszavak: vállalkozássürüség, periféria, területi egyenlötlenség, relatív poziciójavulás JEL-kód: R11

https://doi.org/10.32976/stratfuz.2019.5

\section{Bevezetés}

Egy-egy térség gazdasági erejének alapját a jelen lévő vállalkozások által előállított bruttó hozzáadott érték, az általuk biztosított munkahelyek és befizetett adók jelentik, mert potens helyi gazdaság nélkül hosszú távon nincs a jóléti társadalmak által értelmezett, fenntartható jóllét. A periferikus, halmozottan hátrányos helyzetü térségeink társadalmi, gazdasági és infrastrukturális téren is fokozott lemaradással küzdenek. Az Európai Unióhoz történt csatlakozásunk óta eltelt időben ezen térségek számára számos pénzügyi (hazai és európai uniós források) és szabályozási eszköz (pl: adókedvezmények) állt rendelkezésükre a vállalkozások megtelepedésének elősegítésére és a meglévők megerösítésére (Bihall - Szilágyiné Baán, 2005). Okos helyi fejlesztéspolitika révén sokszor épp a kisebb települések esetén találkozunk olyan jó gyakorlatokkal, ahol a helyi vezetés a különböző eszközök szinergikus, átgondolt stratégia mentén történő alkalmazásával hatékony gazdaságfejlesztést tudott végrehajtani (Nemes - Varga, 2014). Azonban a legtöbb esetben ezek a fejlesztések nem mutatnak túl a helyi önkormányzat hatáskörén, és fenntarthatóságuk sem megoldott, létük sok esetben a támogatásoktól függ (Gerencsér - Tóth, 2017).

A 2007-2013-as Európai Uniós programozási ciklusban a legrosszabb társadalmi-gazdasági mutatókkal jellemezhető, alulfejlett térségek különös figyelmet kaptak a hazai fejlesztéspolitikában, és a lakosság 10 százalékát tömörítő, a hátrányos helyzetü térségek problémáinak ördögi körébe záródott (G. Fekete, 2008) kistérségeink fejlesztésére komplex fejlesztési stratégia kidolgozását tették kötelezővé (Kullman et al. 2010). Ezen térségek egyik legfontosabb fejlesztési területeként a (helyi) gazdaság fejlesztése jelent meg, amely a vállalkozások megjelenésétől a munkalehetőségek bővülését és a helyi tőkekoncentráció növekedését remélte (Margitics, 2010). Bár maga a program a problémákhoz mérten csekély forrásokat különített el a kedvezményezett kistérségek számára, mégis javára írható, hogy ráirányította a figyelmet ezen térségekre, és azok komplex, csak integrált területfejlesztési eszközökkel kezelhető problémájára.

Jelen tanulmány azt vizsgálja, hogy Borsod-Abaúj-Zemplén megyében (amely az európai uniós csatlakozáskor a legtöbb komplex programmal is támogatandó leghátrányosabb helyzetü LAU1 es közigazgatási egységet tömörítette), hogyan változott a megye gazdasági erejének alapját jelentő vállalkozások száma és koncentrációja, különös tekintettel a megye periferikus térségeire. Volt-e lényegi változás a vállalkozássürüségben és a vállalkozások koncentrációjában 
az európai uniós csatlakozás óta eltelt időszakban? Vajon mi áll az egyes járások esetén tapasztalt pozíciójavulások hátterében? Inkább a központi települések (járásszékhelyek), vagy a hinterlandok (az egyes járások járásszékhelyen kívüli települései) esetén tapasztalunk-e markánsabb változásokat?

Kutatásomban periferikus térségnek azokat a járásokat és a hozzájuk tartozó településeket tekintem, amelyek kistérségi jogelődje, vagy annak a jelenlegi központot is magában foglaló része (Putnoki járás) a 2007-es lehatárolás szerint (311/2007. (XI.17.)) komplex programmal támogatandó - a lakosság 10 százalékát tömörítő - 33 leghátrányosabb helyzetű kistérségbe tartozott, amely összesen 11 járást (Ózdi, Putnoki, Edelényi, Mezőcsáti, Szikszói, Encsi, Gönci, Szerencsi, Tokaji, Sárospataki és Cigándi) jelent a jelenlegi közigazgatási beosztásban. Vállalkozások számának alakulására vonatkozó vizsgálataim alapsokaságát az 1 és a feletti létszámú működő vállalkozások jelentik 2004 és 2014 között.

\section{A vállalkozások számának változása: konzerválódó járási szintű koncentrációk}

Borsod-Abaúj-Zemplén megye a működő vállalkozások 5 százalékát koncentrálta országos szinten - a Budapest nélküli vidéki Magyarországnak pedig 6,7 százalékát -, amely 2004 és 2014 közötti 0,6 százalékpontos csökkenése elhanyagolható. Míg 2004 és 2014 között a müködő vállalkozások száma országos szinten növekedett, addig Borsod-Abaúj-Zemplén megyében és annak legtöbb járásában csökkent. Növekedést csak 5 járásban - Gönci, Edelényi, Sátoraljaújhelyi, Putnoki és Tokaji - figyelhettünk meg, amelyek a Sátoraljaújhelyi kivételével periférikus járásnak minősülnek, és növekedési ütemük a Tokaji kivételével meghaladta az országos átlagot (3.ábra). A növekedéshez országos szinten az 1-9 fős létszámkategóriába tartozó vállalkozások számának növekedése járult hozzá. A müködő vállalkozások 95 százalékát e létszámkategória koncentrálta mind országos, mind megyei szinten. Az összes többi létszámkategóriában csökkent a vállalkozások száma. Borsod-Abaúj-Zemplén megyében a megyei átlagot tekintve valamennyi létszámkategóriában csökkent a vállalkozások száma, míg a növekedését realizáló 5 járás esetén - ahogy országosan is - a mikrovállalkozások (1-9 fős) számbeli gyarapodása járult hozzá a vállalkozások számának növekedéséhez.

A megyében a Miskolci járás koncentrálta az időszak elején és végén is a müködő vállalkozások 48 százalékát, a többi járás a 10 százalékot sem érte el (1.ábra). A vállalkozások számának jelentős csökkenése ellenére periférikus járások közül az Ózdi (24 százalékos csökkenés) és Szerencsi (8 százalékos csökkenés) járások a Tiszaújvárosi járással megegyezö mértékben (5 százalék) koncentrálták a müködő vállalkozásokat. Ugyan mindhárom járásban az egyéni vállalkozások voltak túlsúlyban, azonban a Tiszaújvárosi járásban a társas vállalkozások aránya nagyobb, átlagosan 10 százalékponttal magasabb volt. A vállalkozások számának jelentősebb növekedését realizáló járások (3.ábra) is csupán 1 százalékpontot tudtak javítani az általuk a megyén belül koncentrált vállalkozások arányán (1.ábra), vagyis megyei szinten a vállalkozások koncentrációja konzerválódott a vizsgált időszakban, amelyet a 2004 és 2014 között számolt HerfindahlHirschmann index értékének $(0,25)$ stabilitása is jelez, amelynek időszaki szóródása $(0,006)$ elhanyagolható volt. 


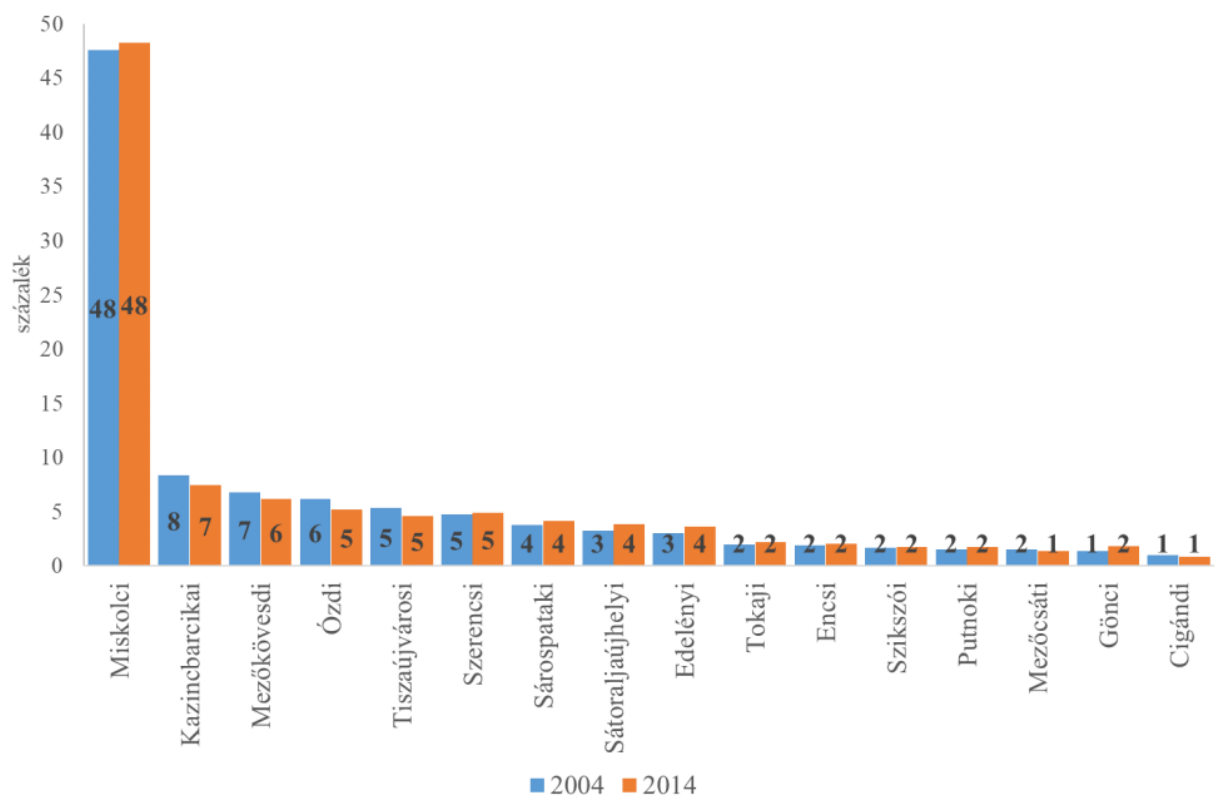

1.ábra: A müködö vállalkozások koncentrációja Borsod-Abaúj-Zemplén megye járásaiban Forrás: TeIR - KSH

\section{Relatív pozíciók átrendeződése a vállalkozássürüség változása alapján}

Az ezer főre jutó vállalkozások száma alapján számított vállalkozássürüség sem 2004-ben, sem 2014-ben nem érte el az országos átlagot (63, illetve 64) egyetlen járásban sem (2.ábra). A megyei átlagot (42, illetve 41) 5 járás haladta meg, amelyek közül kettő, a Tokaji és Sárospataki periférikus járások, amelyekben a vizsgált időszakban nőt a vállalkozássürüség, míg a maradék három (Miskolci, Tiszaújvárosi, Mezőkövesdi), nem periferikus járásban csökkent. A vizsgált idöszakban 7 járásban növekedett a vállalkozássürüség, amelyek közül csak egy, a Sátoraljaújhelyi járás nem volt periférikus, vagyis a periférikus járások több mint felében nőtt az ezer főre jutó vállalkozások száma (1.táblázat).

1.táblázat: Borsod-Abaúj-Zemplén megye járásainak relativ pozíció változása az ezer före jutó vállalkozások száma alapján, 2004 és 2014

\begin{tabular}{l|c|c|c|c}
\multicolumn{1}{c|}{ Járás } & $\begin{array}{c}\text { Vállalkozás- } \\
\text { sürüség 2004 }\end{array}$ & $\begin{array}{c}\text { Relatív pozí- } \\
\text { ció 2004 }\end{array}$ & $\begin{array}{c}\text { Vállalkozás- } \\
\text { sürüség 2014 }\end{array}$ & $\begin{array}{c}\text { Relatív pozí- } \\
\text { ció 2014 }\end{array}$ \\
\hline Miskolci & 57,8 & 1 & 55,9 & 1 \\
\hline Tiszaújvárosi & 50,3 & 2 & 40,3 & 6 \\
\hline Mezökövesdi & 47,0 & 3 & 42,0 & 5 \\
\hline Tokaji & 44,1 & 4 & 49,1 & 2 \\
\hline Sárospataki & 43,6 & 5 & 48,0 & 3 \\
\hline Sátoraljaújhelyi & 39,5 & 6 & 46,8 & 4 \\
\hline Kazincbarcikai & 36,0 & 7 & 31,5 & 8 \\
\hline Szerencsi & 34,2 & 8 & 34,0 & 7 \\
\hline Ózdi & 31,6 & 9 & 26,5 & 12 \\
\hline Mezőcsáti & 30,0 & 10 & 26,4 & 13 \\
\hline Szikszói & 27,5 & 11 & 27,8 & 11 \\
\hline Encsi & 26,5 & 12 & 26,1 & 14
\end{tabular}




\begin{tabular}{l|c|c|c|c}
\multicolumn{1}{c|}{ Járás } & $\begin{array}{c}\text { Vállalkozás- } \\
\text { sürüség 2004 }\end{array}$ & $\begin{array}{c}\text { Relatív pozí- } \\
\text { ció 2004 }\end{array}$ & $\begin{array}{c}\text { Vállalkozás- } \\
\text { sürüség 2014 }\end{array}$ & $\begin{array}{c}\text { Relatív pozí- } \\
\text { ció 2014 }\end{array}$ \\
\hline Edelényi & 26,4 & 13 & 29,7 & 10 \\
\hline Gönci & 24,1 & 14 & 30,2 & 9 \\
\hline Putnoki & 22,5 & 15 & 25,1 & 15 \\
\hline Cigándi & 17,6 & 16 & 14,9 & 16
\end{tabular}

Forrás: TeIR - KSH

A legnagyobb arányú növekedés ezúttal is a Gönci járásban (25,6 százalékos) volt, ezt követte a Sátoraljaújhelyi (18,3 százalékos) - amivel sikerült a megyei átlag felé emelkednie az időszak végére -, majd sorban az Edelényi (12,5 százalékos), Putnoki (11,6 százalékos), Tokaji (11,5 százalékos), Sárospataki (10 százalékos) és végül a Szikszói, amely szinte elhanyagolható 1,1 százalékos növekedést könyvelhetett el.

Az ezer főre jutó müködő vállalkozások száma alapján a 2. ábrán jól látható, hogy a járások 5 csoportba tömörülnek. Az öt csoport közül kettő egyelemü: az egyiket a Miskolci, míg a másikat a Cigándi járás alkotja, amelyek mindkét időszakban a járási rangsor két pólusán jelentek meg. A közöttük elhelyezkedő három csoport tagjai egymástól jól elkülönülnek. Míg a második csoport 40 százalékát, a harmadik csoport felét, addig a negyedik csoportot teljes egészében periférikus járások alkotják.

A második csoportban lévő két periférikus, Tokaji és Sárospataki járás megelőzte a 2004-ben még a Miskolci után második Tiszaújvárosi és Mezőkövesdi járást, így a Tokaji $(49,1)$ a második, a Sárospataki $(48,0)$ a harmadik helyezést érte el az ezer főre jutó müködő vállalkozások tekintetében a megyében az időszak végére. A járások pozíciójavulásának hátterében növekedésük és a 2004-ben jobb helyzetben lévő járások vállalkozássürüségének csökkenése állt.

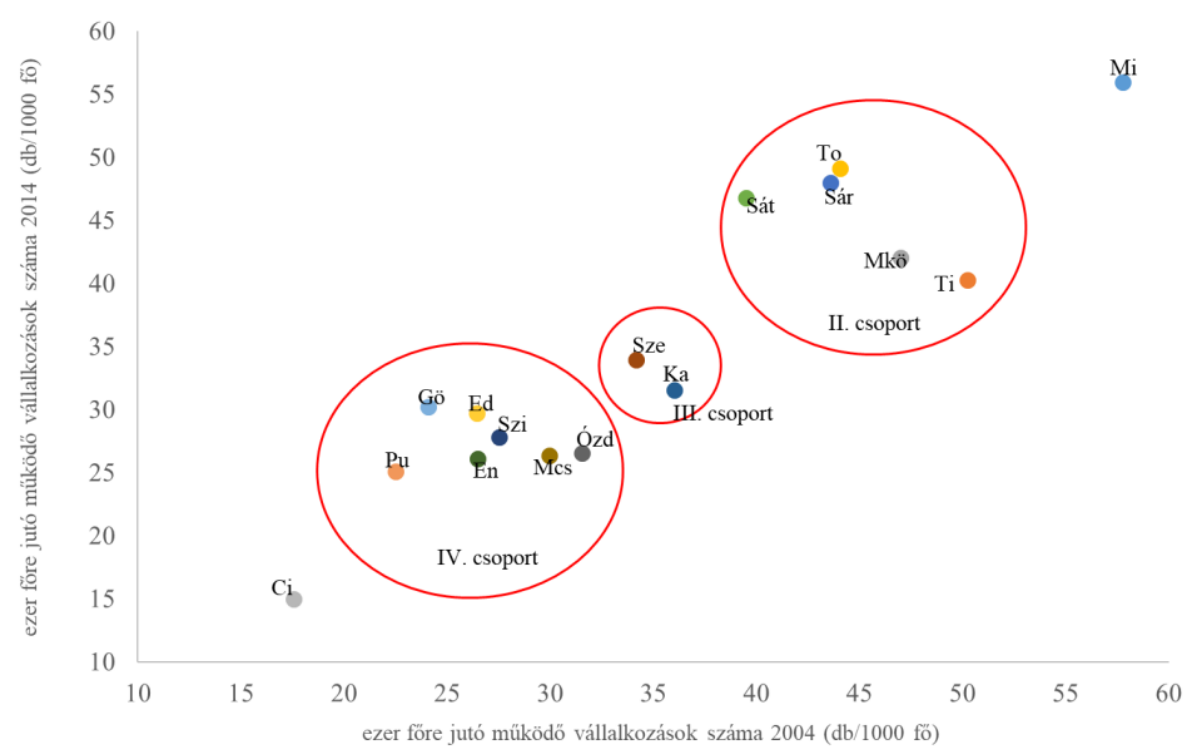

2.ábra: Borsod-Abaúj-Zemplén megye járásai vállalkozássürüségük alapján (2004 és 2014) Forrás: TeIR - KSH

2014-ben a Tokaji és Sárospataki járásokhoz a negyedik helyre a Sátoraljaújhelyi járás $(46,8)$ is felzárkózott, így őket lemaradva az ötödik és hatodik helyen követi csak (1.táblázat) a Mezőkövesdi $(42,0)$ és Tiszaújvárosi $(40,3)$ járás, vagyis a csoportalkotó a 2014-es vállalkozássűrüség és 
nem a hasonló „fejlődési út”. A vállalkozássűrűség összetevőinek változását megvizsgálva azonban azt látjuk, hogy a Tokaji, Sárospataki és Sátoraljaújhelyi járások pozíciójavulásához azok népességcsökkenése nagyobb mértékben hozzájárult, mint a vállalkozások számának növekedése (3.ábra). Különösen igaz ez a Sárospataki járás esetén, ahol a müködő vállalkozások száma lényegében nem változott ( 0,2 százalékos csökkenés), de a Tokaji járás esetén is a vállalkozások számának 1,1 százalékos növekedési ütemét lényegesen meghaladta a népesség 9,3 százalékos csökkenése. A Sátoraljaújhelyi esetén szintén a népességcsökkenés volt nagyobb arányú (10,3 százalék), azonban a vállalkozások számának növekedése is lényegesen magasabb volt (6,2 százalék) az előbbieknél.

A harmadik, kételemü csoportban a Kazincbarcikai és Szerencsi járásokat találjuk, ahol az előbbi jelentős (36-ról 31,5-re), míg utóbbi elhanyagolható (34,2-ről 34,0-ra) mértékủ változása vezetett a két járás közeledéséhez. Bár a Szerencsi járásban (3.ábra) is jelentősebb mértékben csökkent a vállalkozások száma, azonban a népességveszteség is hasonló ütemű volt, ami így a vállalkozássűrüség stagnálását eredményezte. A negyedik csoportba tartozó hét járás közül a Gönci $(30,2)$ és Edelényi $(29,7)$ járás relatív pozíciója javult, és 2014-re jelentős növekedési ütemükkel megközelítették a Kazincbarcikait $(31,5)$ az ezer főre jutó vállalkozások számában, amelyben utóbbi 12 százalékos vesztesége is szerepet játszik. A negyedik csoportba tartozó járások közül még a Putnoki járás értéke növekedett az ezer före jutó vállalkozások tekintetében (22,5-röl 25,1-re), amelyben a népesség számának csökkenése meghatározóbb volt, mint a vállalkozások számának növekedése (3.ábra), azonban ez a változás nem volt elegendő a relatív pozíció javulásához, mindkét időpontban csupán a sereghajtó Cigándi járást előzte meg (1.táblázat). A Putnoki járáshoz hasonlóan a csoportba tartozó Szikszói járás pozíciója (11. helyezett) és értékei $(27,5$, ill. 27,8) sem változtak, amely hátterében a működő vállalkozások számának csökkenését meghaladó népességcsökkenés állt.



3.ábra: A müködö vállalkozások és az állandó népesség számának változása Borsod-Abaúj-

Zemplén megye járásaiban 2004 és 2014 között a bázisév százalékában (100\%=0, járások sorrendje balról jobbra = az ezer före jutó vállalkozások 2014-es csökkenö rangsorrendje)

Forrás: TeIR - KSH 
A járások abszolút (önmagukhoz képesti) növekedése korántsem jelenti a relatív pozíciójuk javulását, ahogy ezt a Putnoki járás esetén is láttuk. Összességében elmondható, hogy a megyében a Sárospataki, Tokaji, Sátoraljaújhelyi, Szikszói és Putnoki járások kivételével a vállalkozássürüség változásában a vállalkozások számának változása nagyobb szerepet játszott, mint a népesség változása. A megyében a vállalkozássürüség alapján 6 járásnak javult a pozíciója, amelyből 5 periférikus járás volt: Tokaji, Sárospataki, Szerencsi, Gönci és Edelényi. Ezek közül míg a Tokaji, Sárospataki és Szerencsi esetén a népesség csökkenés következtében javult a relatív pozíciót meghatározó vállalkozássürüség, ami az enyhén növekvő (Tokaji), stagnáló (Sárospataki), vagy csökkenő (Szerencsi) vállalkozások száma ellenére pozíciójavulást eredményezett, addig a Gönci járás esetén egyértelműen magas arányban, míg az Edelényi esetén egyértelmủen, de kisebb arányban a vállalkozások számának növekedése járult hozzá a pozíciójavuláshoz. A Gönci öt, az Edelényi három helyezést javított relatív pozícióján, amely a legnagyobb mértékü volt a megyében. A vállalkozások számának növekedése főként a mikorvállalkozásokra esik, de a magasabb növekedést realizáló járások a magasabb létszámkategóriába is elöre törtek.

\section{Gyengülő járásszékhelyek, erősödő hinterlandok}

A müködő vállalkozások számának országos szinten tapasztalt növekedését elsősorban Budapest és országos összesítésben a járásszékhelyeken kívüli települések (hinterland) növekedése okozta, miközben a székhelytelepüléseken csökkent a müködő vállalkozások száma (5.ábra). Míg Borsod-Abaúj-Zemplén megyében összesítésben mind a székhelytelepüléseken, mind a hinterlandok tekintetében csökkent a müködő vállalkozások száma, addig az ezer főre jutó vállalkozások száma a hinterlandokon növekedett, ami egyértelmüen a népesség számának a müködő vállalkozásokat meghaladó ütemével magyarázható. Borsod-Abaúj-Zemplén megye székhelytelepülésein pedig a müködő vállalkozások számának csökkenése nagyobb mértékben járult hozzá az ezer főre jutó vállalkozások számának csökkenéséhez, mint a népesség csökkenése.

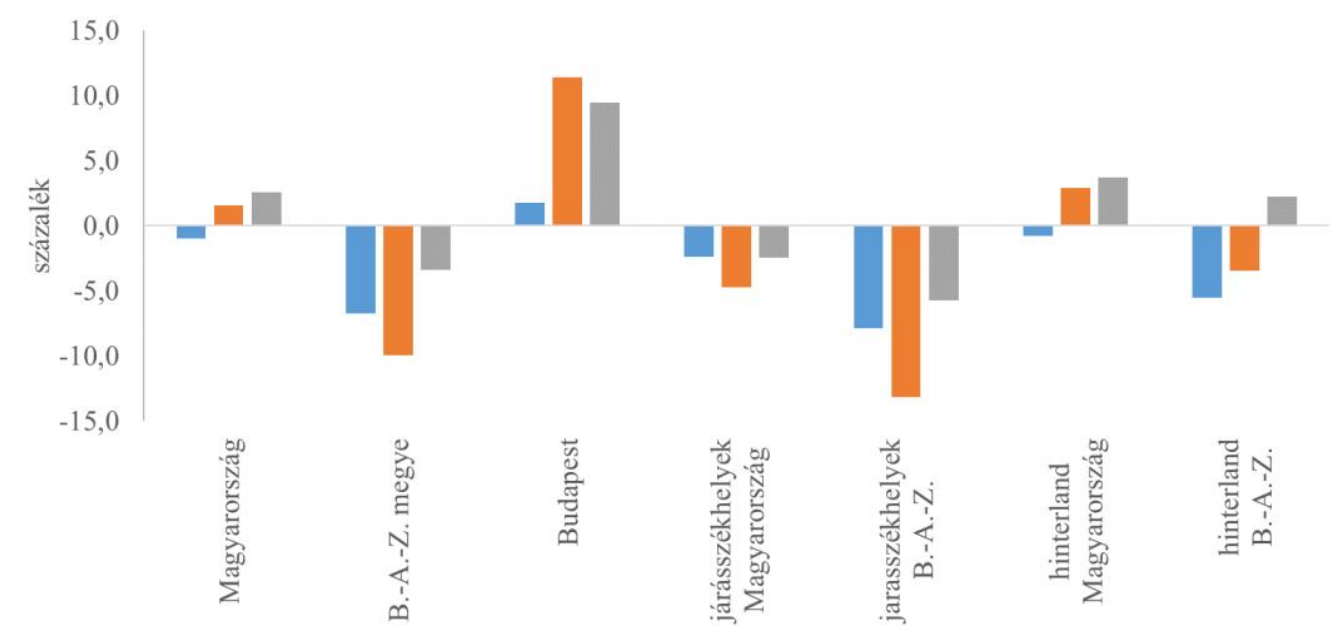

" népesség növekedési rátája = müködő vállalkozások növekedési rátája = vállalkozássűrüség növekedési rátája

4.ábra: A müködő vállalkozások és az állandó népesség számának változása 2004 és 2014 között a bázisév százalékában $(100 \%=0)$

Forrás: TeIR - KSH

Az ezer főre jutó vállalkozások száma esetén 2004 és 2014 között növekedést realizáló járások - Tokaji, Sárospataki, Sátoraljaújhelyi, Gönci, Edelényi és Putnoki - esetén a Tokaji ki- 
vételével mindenhol a hinterland növekedése számottevőbb volt, mint a székhelytelepülés növekedése, sőt a Gönci és Putnoki járás esetén a székhelytelepülés csökkenését tapasztalhatjuk (5a.ábra). Fentebb a járási szintü vizsgálat esetén arra a megállapításra jutottunk, hogy az Edelényi és Gönci járások kivételével nem a vállalkozások számának növekedése, hanem a népességcsökkenés volt az, ami a vállalkozássürüség növekedését előidézte.




$5 b$.

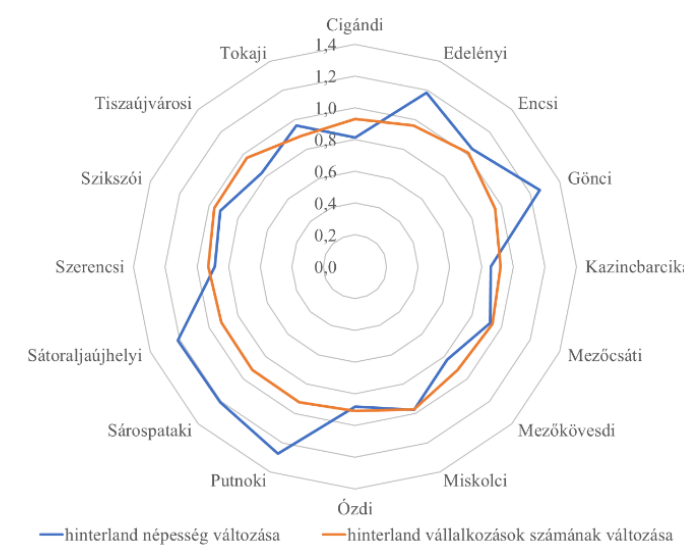

$5 c$.

5a-c.ábra: A vállalkozássürüség, a népesség és müködö vállalkozások számának változása Borsod-Abaúj-Zemplén megye járásaiban 2004 és 2014 között (1 feletti érték növekedés, egy alatti csökkenést jelez)

Forrás: TeIR - KSH

Putnoki járás esetén a hinterland vállalkozássürüsége növekedett, ahol a vállalkozások számának növekedése arányaiban nagyobb volt, mint a népesség számának csökkenése, de az ellentétes előjelű mozgásuknak köszönhetően az ezer főre jutó vállalkozások számának növekedéséhez szinergikusan járultak hozzá. A hinterland vállalkozásszámának növekedése, azonban alig haladta meg a járásszékhely vállalkozásainak csökkenését, így a két folyamat kiegyenlítő hatásaként járási szinten alig 3 százalékkal nőtt a vállalkozások száma, amitől arányaiban nagyobb mértékben csökkent a népesség, amely járási szinten a vállalkozások számának népességarányos növekedésében realizálódott.

A Tokaji kivételével a hinterland esetén a vállalkozások számának emelkedésével és a székhelytelepülés esetén a vállalkozások számának csökkenésével számolhatunk, és ugyancsak a Tokaji járás kivételével a székhely népességcsökkenése minden esetben gyorsabb volt a hinterland né- 
pességcsökkenésénél. Az Edelényi és Sárospataki járás esetén a székhely esetén a népesség csökkenése hasonló arányú volt, mint a vállalkozásoké, ebből adódóan lényegében stagnált (1 százalékos növekedés) a vállalkozássürüség értéke. Szintén a járásszékhely erősödése figyelhető meg a Sátoraljaújhelyi járás esetén, ahol a vállalkozások számának lényegében stagnálása (1 százalékos növekedés) mellett a népesség több mint 10 százalékpontos csökkenését figyelhetjük meg, amely a székhely növekedését eredményezte. A járási szinten a vállalkozássürüség növekedését realizált járások esetén a Tokajit kivéve a hinterlandok esetén a vállalkozások számának növekedését (18 és 27 százalék között szóródva) és a népesség attól jóval elmaradó arányú ( 9 és 4 százalékpont között szóródó) csökkenését figyelhetjük meg, így ez esetben a vállalkozássürüség növekedésének mértékében a vállalkozások számának növekedése játszott jelentősebb szerepet, miközben az ellenkező irányú folyamatok eredője összeadódva járult hozzá a tapasztalt változásokhoz.

A Tokaji járásban ugyan mind a székhelytelepülés (14 százalékos), mind a hinterland (8 százalékos) esetén a vállalkozássürüség növekedésének lehetünk tanúi, azonban a Tokaji a Sátoraljaújhelyi mellett az egyetlen, ahol nőtt a székhelytelepülésen a vállalkozások száma és csökkent a hinterland esetén, illetve a hinterlandon a székhelytelepülést meghaladó mértékben csökkent a népesség száma, így a hinterland esetén egyértelmüen a népességcsökkenés okozta csak a vállalkozássürüség emelkedését, a székhely esetén pedig a vállalkozások számának enyhe növekedése és a népesség számának csökkenésének eredője okozta a vállalkozássürüség növekedését.

A vizsgált időszakban a Gönci (85), a Sátoraljaújhelyi (64), az Edelényi (63), a Putnoki (15) és a Tokaji (7) járás ért el pozitív mérleget a müködő vállalkozások száma változásának tekintetében, amely járások vállalkozássürüsége is növekedett a vizsgált időszakban. Azonban míg a Tokaji járás vállalkozássürüségének jelentős növekedéséhez a népesség csökkenésének üteme járult hozzá, addig a többi esetén a hinterlandokon a vállalkozások számának növekedése jelentősebb volt a megfigyelhető népességcsökkenéssel szemben. A Gönci és Edelényi járás relatív pozíciójavulásához (két legnagyobb) a működő vállalkozások számának növekedése járult hozzá néhány településen. Míg a Gönci járás növekedését elsősorban Göncruszka (18) ${ }^{15}$, Mogyoróska (13), Fony (8), Abaújkér (7), Hidasnémeti (7), Hejce (6), addig az Edelényi járás esetén a növekedéshez Teresztenye (15), Boldva (14), Abod (12), Ládbesnyő (9), Galvács (7), Becskeháza (6) települések járultak hozzá.

A vállalkozások számának népességarányos településszintü vizsgálatából kitünik azonban, hogy valóban a Gönci, Sátoraljaújhelyi és Edelényi járás az, ahol a legtöbb településen jelentős mértékben változott a vállalkozások aránya, azonban, ahogy az a 6.ábrán is látható a térbelileg koncentráltan megjelenő, nagyobb összefüggő térséget alkotó települések nem egy-egy közigazgatási egységhez tartoznak, hanem kiterjedésük túlmutat a közigazgatási határokon, és föként az észak zempléni területeken alkotnak összefüggő térséget.

\footnotetext{
${ }^{15}$ Zárójelben a müködő vállalkozások számának emelkedése 2004 és 2014 között.
} 


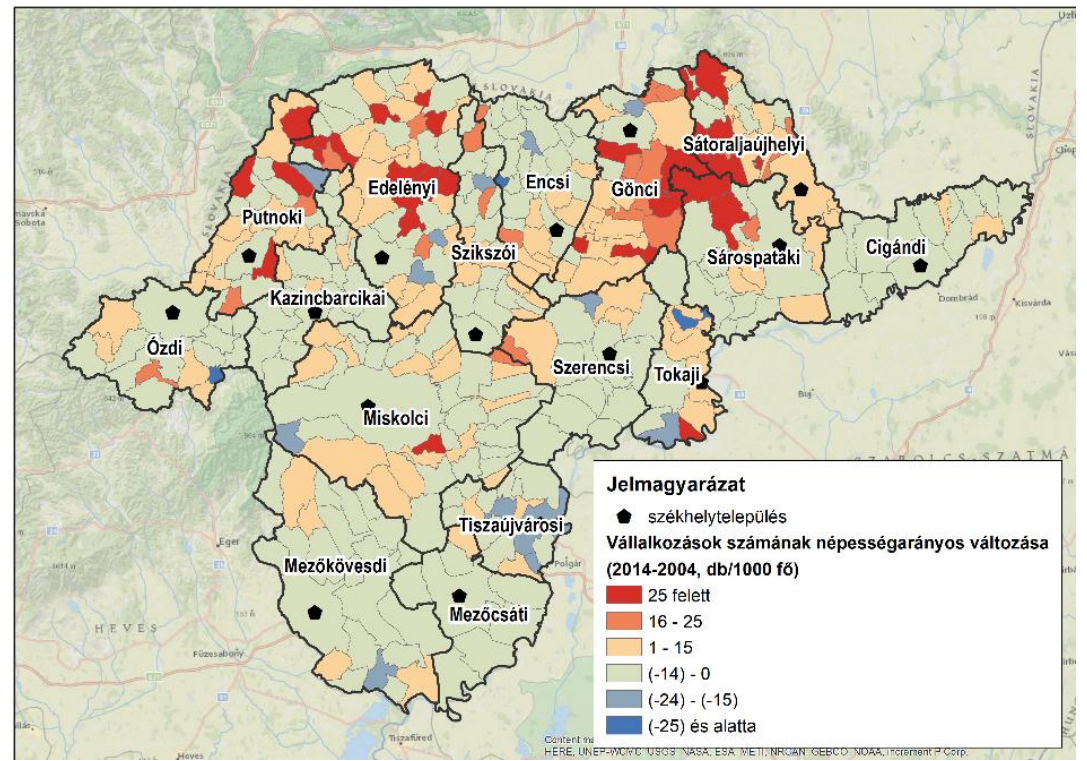

6.ábra: A müködő vállalkozások számának 2004 és 2014 közötti változása a 2014-es népesség ezrelékében Borsod-Abaúj-Zemplén megye településein

Forrás: TeIR - KSH

\section{Összefoglalás}

A vizsgált időszakban Borsod-Abaúj-Zemplén megyében a járások 37,5 százaléka ért el pozíciójavulást, összesen 6 járás, amelyek egy (Sátoraljaújhelyi) kivételével periférikusak voltak. Az öt periférikus járásból összesen két járásban, a Gönciben és Edelényiben - amelyek a megyében a legnagyobb pozíciójavulást érték el - növekedett valóban számottevően a müködő vállalkozások száma, míg a többi (Tokaji, Sárospataki és Szerencsi) esetén inkább a népességcsökkenés okozta a megyei sorrend kialakításának alapjául szolgáló vállalkozássürüség növekedést. A relatív pozíciójavulásokhoz természetesen a megye vezető járásainak vállalkozássürüségében bekövetkezett jelentős csökkenés is hozzájárult, azonban e folyamatok nem voltak olyan mértékủek, hogy érdemben módosítani tudták volna a megyében az időszak elején meglévő koncentrációs viszonyokat.

A vállalkozássürüség hátterében álló területi egyenlőtlenségeket megvizsgálva azt tapasztalhattuk, hogy a Tokaji járás kivételével a hinterland esetén a vállalkozások számának emelkedésével és a székhelytelepülés esetén a vállalkozások számának csökkenésével számolhatunk, és ugyancsak a Tokaji járás kivételével a székhely népességcsökkenése minden esetben gyorsabb volt a hinterland népességcsökkenésénél. A jelentős pozíciójavulást elért járások (Gönci és Edelényi) esetén pedig egyértelműen a hinterland, annak településeinek nagy részére kiterjedő vállalkozássürüségének a járásszékhely csökkenését is kompenzáló növekedése járult hozzá.

A kutatás arra hívja fel a figyelmet, hogy a nem feltétlenül népességhez kötődő gazdasági jellemzők népességarányos vizsgálata félreviheti a kutatót az egyes területi egységek növekedésének, fejlődésének megítélésében. Hiszen míg például a jövedelmi mutatók esetén igaz, hogy a népesség csökkenésével az arányosan csökken és a népességcsökkenés ellenére az egy före jutó növekedés a helyi lakosság jólétének emelkedését tükrözi, addig a vállalkozások száma esetén ez nem feltétlenül van így, hiszen lehet épp az a népesség vándorol el, aki a helyi vállalkozások- 
nál egyébként sem kapott munkát, vagyis nem növeli feltétlenül a vállakozássürüség pusztán elvándorlás következtében történő növekedése a helyi társadalom jólétét ${ }^{16}$.

\section{Irodalomjegyzék}

BIHALL T. - SZILÁGYINÉ BAÁN A. (2005): Borsod-Abaúj-Zemplén megye gazdaságának helyzete az EU-csatlakozás után másfél évvel. Esélyek, lehetőségek, kockázatok, Észak-Magyarországi Stratégiai Füzetek, II. évf., 2.sz. pp.45-64

G. FEKETE É. (2008): A fejlődés és versenyképesség értelmezése kevésbé fejlett térségekben, In Lengyel I. - Lukovics M. (szerk.) : Kérdőjelek a régiók gazdasági fejlődésében. JATEPress, Szeged, pp. 130-152.

GERENCSÉR I. - TÓTH T. (2017): „Lesz ez még így sem” avagy a településvezetők helyi szerepe a fejlesztésekben két település példáján keresztül, Studia Mundi - Economica, Vol.4. No.4. pp.2-11. https://doi.org/10.18531/Studia.Mundi.2017.04.04.2-11

KULLMAN Á. - JANZA F. - HERCZEG B. (2010): A leghátrányosabb helyzetü kistérségek célzott támogatásának kísérlete, és elsőtapasztalatai Észak-Magyarországon, ÉszakMagyarországi Stratégiai Füzetek, VII. évf., 2. szám, pp.3-20.

MARGITICS GY. (2010): Észak-magyarországi LHH-s tapasztalatok - regionális ügynökségi nézőpontból, Észak-Magyarországi Stratégiai Füzetek, VII. évf., 2. szám, pp.52-57.

NEMES G. - VARGA Á. (2014): Gondolatok a vidékfejlesztésről - alrendszerek találkozása, társadalmi tanulás és innováció, Educatio, 2014/3. pp. 384-393.

${ }^{16}$ Maximum csak bizonyos aspektusokban: a befizetett adóból több jut fajlagosan egy-egy lakosra, azonban ezt számos egyéb változó is befolyásolja még. 